\title{
Herniotomy Alone as Treatment for Scrotal Migration of Ventriculoperitoneal Shunt
}

\author{
Balamurugan Rajendran*, Prabu Rau Sriram and Ananda Arumugam \\ Department of Paediatric Neurosurgery, Sabah Women \& Child Hospital Likas, Malaysia
}

Submission: February 14, 2018; Published: June 13, 2019

*Corresponding author: Balamurugan Rajendran, Department of Paediatric Neurosurgery, Sabah Women and Child Hospital Likas, Sabah, Malaysia

\begin{abstract}
Complication rate of ventriculoperitoneal (VP) shunt is from 11\%-25\%; differs from centre to centre. One of the rare complications of ventriculoperitoneal shunt is distal catheter migration into various abdominal contents including the scrotum. A few cases of scrotal migration of distal catheter have been reported in paediatric patients with different managements. Here we report a case of a 3-year-old child who presented with a right sided hydrocele with the distal end of the shunt in the left hemiscrotum 3 years following a VP shunt placement for congenital hydrocephalus. Herniotomy alone was our management in this case.
\end{abstract}

Keywords: Ventriculoperitoneal shunt; Scrotal migration; Herniotomy

\section{Introduction}

Ventriculoperitoneal (VP) shunts are the most commonly performed operative procedures to treat hydrocephalus in children [1]. Shunt migration is one of the rare complications of VP shunt yet there are a few case reports have reported migration to the scrotum via patent Processus vaginalis due to the frequent incidence of shunt placement. In this article we report a rare case; the first out of 180 VPS done in the hospital; who presented with scrotal migration of VP shunt.

\section{Case History}
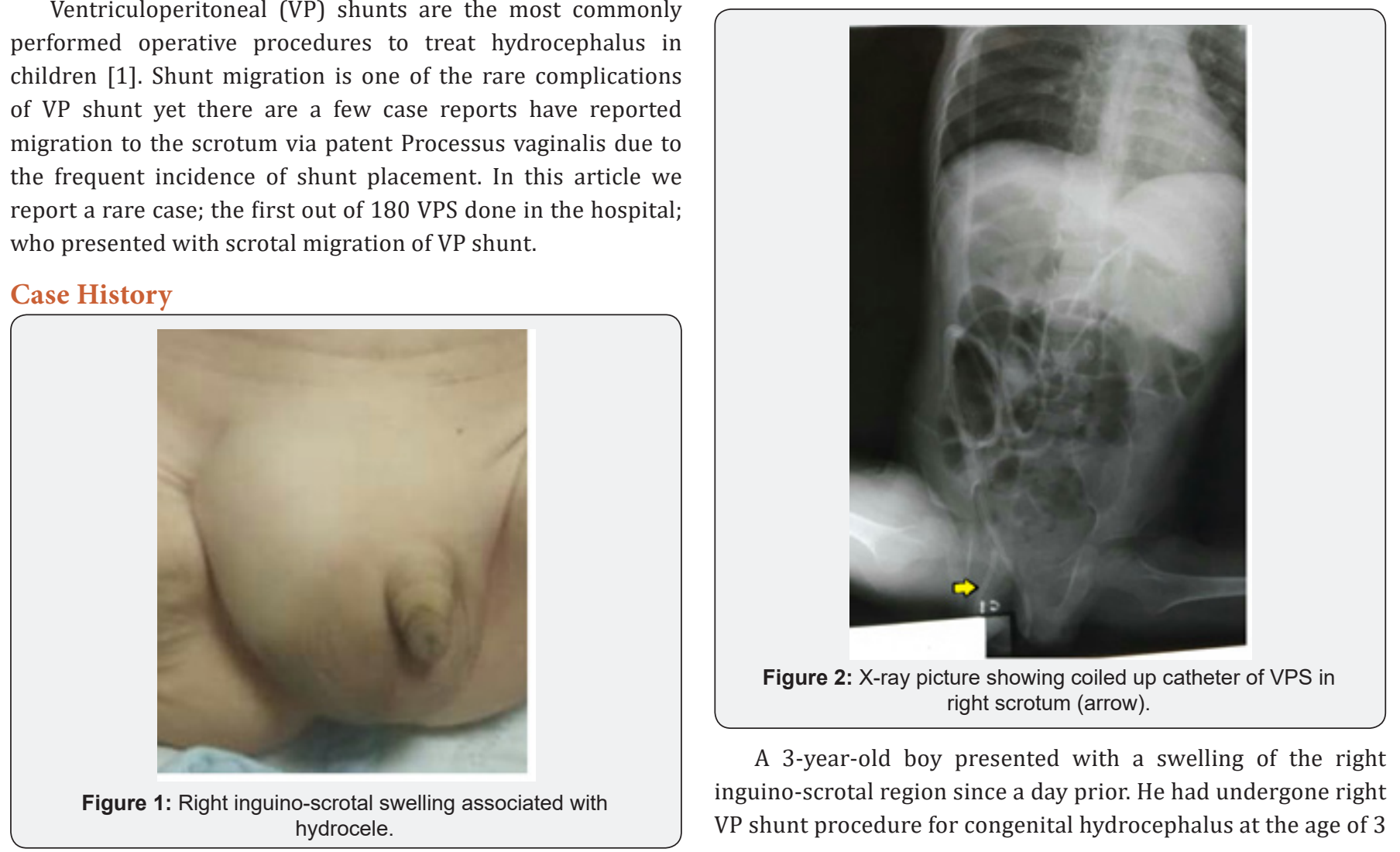

A 3-year-old boy presented with a swelling of the right inguino-scrotal region since a day prior. He had undergone right VP shunt procedure for congenital hydrocephalus at the age of 3 
months. The swelling was not associated with any complains of pain, fever or features of intestinal obstruction. On examination a gross swelling was noted in the right scrotal region (Figure 1). There were no clinical features of shunt malfunction. An X-ray of the abdomen and pelvis showed that the peritoneal end of the shunt coiled in the scrotum with its tip inside the abdomen (Figure 2). Patient asymptomatic of raised ICP and shunt block.

Patient was then planned for herniotomy. Prior incision, swelling could be reduced under general anaesthesia easily. Exploration was done subsequent revealed a thicken sac with empty contents and excised completely. VP shunt catheter was reduced with hernia sac preoperatively; the catheter was not visualized intraoperative. Post-operative X-ray confirmed the replaced entire distal shunt in abdomen (Figure 3). The patient is currently asymptomatic and doing well at follow-up.

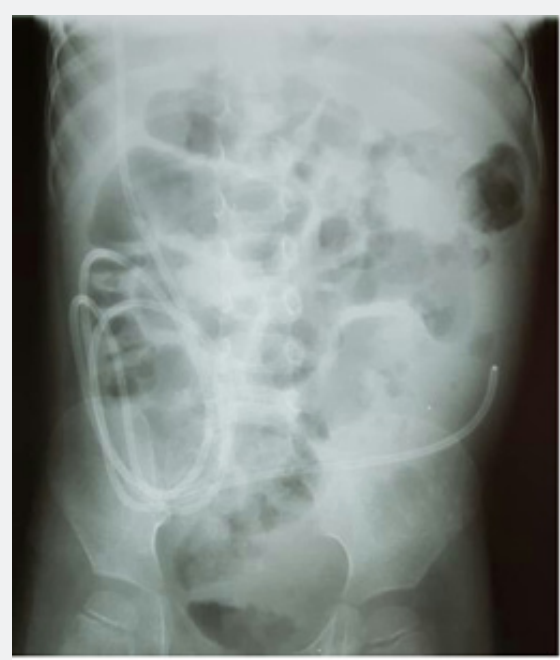

Figure 3: X-ray picture showing distal catheter of VPS entirely in abdomen.

\section{Discussion}

VP shunt insertion is a common treatment for hydrocephalus. The distal catheter of VP shunt can migrate into various body parts including the ventricle, scalp/subgaleal space, mouth, neck, breast, breast implant, thoracic cavity, pulmonary artery, intracardiac, lungs/pleural space/transdiaphragmatic, anterior chest wall, intraabdominal wall, abdominal subcutaneous fat tissue, umbilicus, stomach, large intestine, liver, gall bladder, bladder/urethra, inguinal sac, buttocks, canal of Nuck, which is the female counterpart of the spermatic cord, vulva/vagina, rectum/anus, and knee [3]. The reported incidence of distal migration of VP shunt is $10 \%$ [4]. But only less than 40 cases have been reported on scrotal migration of distal end of the shunt, as it is a rare phenomenon [5].
Normally, Processes vaginalis is patent at $60-70 \%$ of infants in first three months of life. It could be established as patent at $50-60 \%$ of 1 -year olds and $40 \%$ for children between ages 2-16 years [6]. Increased abdominal pressure following shunt insertion may prevent obliteration of the Processus vaginalis and facilitates migration of the VP shunt into the scrotum [2]. Smaller size of peritoneal cavity in infancy compared with older children could be another etiologic factor for VP shunt migration to Processus vaginalis [7].

Scrotal migration of the distal VP shunt can lead to secondary hydrocoele, incarceration of catheter, and shunt malfunction, which in turn can cause worsening of the hydrocephalus [5]. A plain radiographic shunt series should be performed to assess integrity of VP shunt and plain computed tomography scan is needed to reassess the severity of hydrocephalus.

Management differs from case to case basis. The most common management encompassed shunt revision and herniotomy. Out of 36 cases reported 27 cases was managed with herniotomy and shunt revision and another 8 cases with shunt revision with no herniotomy done. Only 1 case was managed via herniotomy alone alike this case with manual compression of swollen scrotum [5].

\section{References}

1. CP Bondurant, DF Jimenez (1995) Epidemiology of cerebrospinal fluid shunting. Pediatr Neurosurg 23(5): 254-258.

2. Sarangi GS, Mohanty S, Rout SS (2016) Late onset scrotal migration of the distal catheter of a ventriculoperitoneal shunt in a 4-year-old male with post meningitic hydrocephalus-a case report and review of literature. International Surgery Journal 3(1): 390-393.

3. Ricci C, Velimirovic BM, Fitzgerald TN (2016) Case report of migration of 2 ventriculoperitoneal shunt catheters to the scrotum: use of an inguinal incision for retrieval, diagnostic laparoscopy and hernia repair. Int J Surg Case Rep 29: 219-222.

4. Sharifian A, Abdollahi A, Maddah G, Anaraki F, Alvandipour M, et al. (2013) Spontaneous transanal protrusion of ventriculoperitoneal cathether: a case report. Acta Med Iran 51(2): 135-138.

5. Kita D, Hayashi Y, Kinoshita M, Ohama K, Hamada J (2010) Scrotal migration of the peritoneal catheter of a ventriculoperitoneal shunt in a 5-year-old male Case report. Neurol Med Chir (Tokyo) 50(12): 11221125.

6. Bawa M, Garge S, Garg R, Narasimha Rao KL (2017) Scrotal migration of tubing: An unusual complication after ventriculo-peritoneal shunt. Asian J Neurosurg 12(4): 738-740.

7. Jamjoom A, Ur-Rahman N, Jamjoom ZA, Jawad A, Fadley F (1992) Unique complications of cerebrospinal fluid shunts in children - a report of two cases. Neurochir (Stuttg) 35(5): 156-159. 
This work is licensed under Creative Commons Attribution 4.0 License DOI: 10.19080/JHNSS.2019.03.555623

\section{Your next submission with Juniper Publishers will reach you the below assets}

- Quality Editorial service

- Swift Peer Review

- Reprints availability

- E-prints Service

- Manuscript Podcast for convenient understanding

- Global attainment for your research

- Manuscript accessibility in different formats ( Pdf, E-pub, Full Text, Audio)

- Unceasing customer service

Track the below URL for one-step submission https://juniperpublishers.com/online-submission.php 